\title{
APRESENTAÇÃO
}

\section{Diagnóstico Pré-Natal e Aborto Seletivo}

DEBORA DINIZ

O debate ético sobre a nova genética cresceu nos anos 1990, vindo a constituir tema central na bioética. $O$ avanço das modernas técnicas de diagnóstico pré-natal, em especial da amniocentese, reacendeu as discussões éticas sobre a moralidade do aborto. A institucionalização da profissão de "aconselhadora genética" nos Estados Unidos, um campo disciplinar a meio caminho do Serviço Social e da Genética Clínica, introduziu definitivamente o tema do aborto seletivo no contexto das decisões éticas do pré-natal ${ }^{1}$. Para a bioética, o avanço da nova genética e a construção de um novo saber, o do aconselhamento genético, provocaram uma grande surpresa: o revigoramento do debate sobre a moralidade do aborto.

Até aquele momento, havia certo consenso internacional de que o aborto deveria ser uma questão de foro íntimo. Esse acordo tácito da bioética se justifica pelos fundamentos liberais da bioética, em especial por princípios éticos como autonomia ou liberdade. A controvérsia sobre a moralidade do aborto, entretanto, nunca deixou de estar ativa, fazendo-se presente de forma particularmente intensa em fóruns feministas ou religiosos. A América Latina é um caso exemplar de região onde o tema do aborto vem sendo questão persistente, muito embora seja apenas superficialmente enfrentada pela reflexão bioética.

Foi nesse contexto de relativa tranqüilidade sobre o aborto que surgiu a crítica expressivista de Adrienne Asch. Esta era ainda uma estudante de doutorado em filosofia em início dos anos 1990, quando lançou o argumento de que o aborto por anomalia fetal, também conhecido por aborto seletivo, era um tema delicado para as comunidades de deficientes. Segundo ela, diferentemente de todas as outras situações de aborto voluntário, em que a soberania da liberdade reprodutiva poderia ser considerada um princípio incontestável, o aborto seletivo deveria também ser analisado à luz dos direitos e interesses dos deficientes. A crítica de Asch ficou conhecida como "expressivista", pelo argumento inicial de que uma mulher, ao optar pela 
interrupção da gestação de um feto portador de má-formação, enviaria uma mensagem negativa aos deficientes com aquela mesma lesão. Além do pressuposto da mensagem, Asch sugeria que o fundamento da decisão pelo aborto seletivo era a crença na inferioridade da vida com deficiência, ou seja, o aborto seria forma de expressão da subalternidade dos deficientes em nossas sociedades. E, para Asch, assim como para inúmeras outras pesquisadoras da deficiência que a seguiram, as modernas técnicas de diagnóstico pré-natal e a popularização do aborto seletivo poderiam se converter em uma ameaça à integridade e à dignidade dos deficientes.

Asch carregava consigo a legitimidade de ser uma feminista cega, tendo sido uma das primeiras mulheres deficientes a escrever sobre bioética e, ainda, uma das poucas a ser reconhecida internacionalmente. Suas idéias foram tema de simpósios, debates internacionais, livros, monografias, teses e centenas de artigos nos melhores e mais importantes periódicos de saúde pública, ética, direitos humanos e bioética. O Hastings Center Reports, um dos periódicos mais antigos e importantes da pesquisa bioética internacional, dedicou um volume à reflexão da crítica expressivista. Mas o tamanho do desafio teórico e político de Asch não é pequeno. Por um lado, seu argumento se ampara em premissas feministas da liberdade reprodutiva, mas, por outro, avalia o impacto do exercício da liberdade das mulheres na vida dos deficientes. Esse cruzamento das premissas feministas e dos compromissos do modelo social da deficiência vem sendo o nó argumentativo das idéias de Asch.

O modelo social da deficiência foi um movimento sociológico e político surgido nos anos 1960 e 1970 no Reino Unido e nos Estados Unidos. O argumento central do movimento social da deficiência era que a experiência de opressão, abandono e desigualdade sofrida pelos deficientes era antes o resultado dos arranjos sociais e políticos do que mesmo das limitações físicas ou mentais do corpo deficiente. O impacto desse argumento foi imenso, especialmente pela crítica explícita aos modelos biomédicos de controle e domesticação da deficiência, em que o deficiente era reduzido à lesão. $\mathrm{O}$ modelo social foi uma tentativa exemplar de resistência à medicalização da deficiência. Asch aproximou o debate bioético e feminista do modelo social da deficiência, ao argumentar que, muito embora o aborto voluntário devesse ser considerado amoral, seriam necessários limites morais ao aborto seletivo.

A proposta dos limites morais foi rapidamente retirada do cenário argumentativo de Asch. Se os primeiros escritos ainda continham alguma ambição controlista da reprodução, esse tom se dissipou nas publicações 
mais recentes, que se caracterizam antes pela promoção da dignidade do deficiente que mesmo por discutir a moralidade do aborto seletivo. A despeito da guinada argumentativa de Asch, um ponto merece ser destacado em todo o desenvolvimento da crítica expressivista: Asch jamais buscou fundamentos morais para a crítica expressivista na retórica da discussão tradicional sobre o aborto. O feto, para Asch, não é pessoa, não é detentor de direitos ou interesses e não há qualquer possibilidade de se pensar em conflitos de interesses entre a mulher grávida e o feto. Asch está preocupada com a vida e o bem-estar dos deficientes que vivem entre nós, aqueles consensualmente considerados pessoas e sujeitos de direitos.

Dado o impacto das idéias de Asch no contexto bioético internacional, traduzimos um de seus artigos mais recentes sobre a moralidade do aborto seletivo, "Diagnóstico Pré-natal e Aborto Seletivo: Um Desafio à Prática e às Políticas", publicado originalmente no American Journal of Public Health. Os artigos que acompanham o de Asch, de Debora Diniz e Alessandra Barros, dialogam com os argumentos da autora, e trazem nuanças da realidade brasileira. Esse conjunto de texto tem a intenção de provocar o debate sobre a moralidade das novas técnicas de diagnóstico pré-natal e do aborto seletivo, e contribuir para renovar a discussão do aborto no Brasil.

\section{NOTA}

1 O uso do gênero feminino se justifica pelo fato de $99 \%$ das profissionais do aconselhamento genético nos Estados Unidos serem mulheres. 